\title{
Crankshaft Design Optimality and Failure Analysis: A Review
}

\author{
Manish Kumar ${ }^{1}$, Shiv N Prajapati ${ }^{2}$ \\ ${ }^{1}$ Faculty, Manufacturing Technology, Central Institute of Plastics Engineering and Technology, Lucknow, India \\ ${ }^{2}$ Faculty, Mechanical Engineering, NIET, Greater Noida, India
}

\begin{abstract}
The crankshaft in an internal combustion engine converts the linear reciprocating motion of the piston into a rotary motion with a four link mechanism. A crankshaft works in variably complicated conditions, and is subjected to torsional loads due to inertia of rotating components and bending loads due to gas pressure in internal combustion engines. Its behavior is affected by the fatigue phenomenon due to the reversible cyclic loadings. When repetitive tensile and compressive stresses are developed due to reversible cyclic loadings it leads to fatigue phenomenon which can cause dangerous ruptures and damages. Since a crankshaft is a highly stressed component in an engine, fatigue performance and durability of this component has to be considered in the design process Fatigue is the primary cause of failure of crankshafts in internal combustion engines. In this review paper, the design and forces analysis is carried out and fatigue phenomenon in crankshaft and optimal design is studied.
\end{abstract}

Keywords: Crankshaft. Fatigue, SWT, Web, Monotonic

\section{Introduction}

A crankshaft has a very wide range of applications from small one cylinder lawnmower engines to very large multicylinder marine engines [2]. The crankshaft consists of the shaft parts which revolve in the main bearings, the crankpins to which big ends of the connecting rod are connected, the crank arms or webs (also called cheeks) which connect the crankpin and the shaft parts.

The crankshaft has large weights, called counter weight, which balance the weight of the connecting rod. These weights ensure an even (balance) force during the rotation of the moving part. The crankshaft main journals rotate in a set of supporting bearings ("main bearings") as shown in Figure.1 [1].

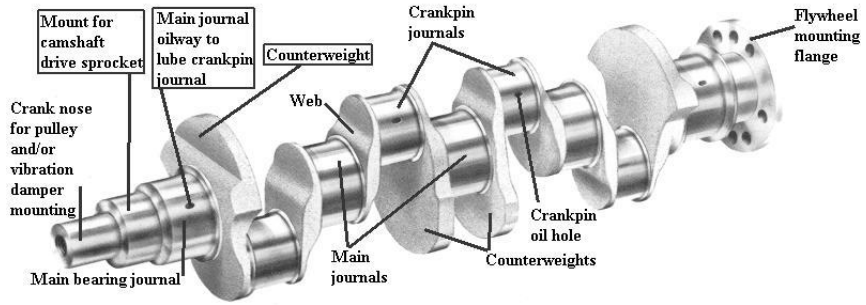

Figure 1: Typical crankshaft with main journals [3]

\subsection{Background}

Chatterley et al. [4] compared the fatigue performance of crankshafts made from ductile iron, austempered ductile iron (ADI), and forged steel. They manufactured ductile iron and ADI crankshafts similar to forged steel crankshaft and each crankshaft were clamped at the two main bearings. Williams, J. and Fatemi [2] conducted monotonic tensile tests as well as strain-controlled fatigue tests on crankshaft specimen, in order to obtain the monotonic and cyclic deformation behavior, and fatigue properties of material. Dubensky [5] discussed the conceptual design processes for a crankshaft that requires input design data from the engine specifications and operating conditions. Since crankshafts have complex geometries, warm and cold forging of the component is not possible. Therefore, crankshafts are manufactured using the hot forging process. Forgings offer a high strength to weight ratio, toughness, and resistance to impact and fatigue, which are important factors in crankshaft performance [6].

\section{Failure of Crankshaft under Bending and Torsion}

The crankpin is like a built in beam with a distributed load along its length that varies with different crank angle position. Each web like a cantilever beam subjected to bending \& twisting. Journals would be principally subjected to twisting as shown in Figure 2. Following stresses are developed in the crankshaft:

- Bending causes tensile and compressive stresses.

- Twisting causes shear stress.

- Due to shrinkage of the web onto the journals, compressive stresses are set up in journals \& tensile hoop stresses in the webs [7].

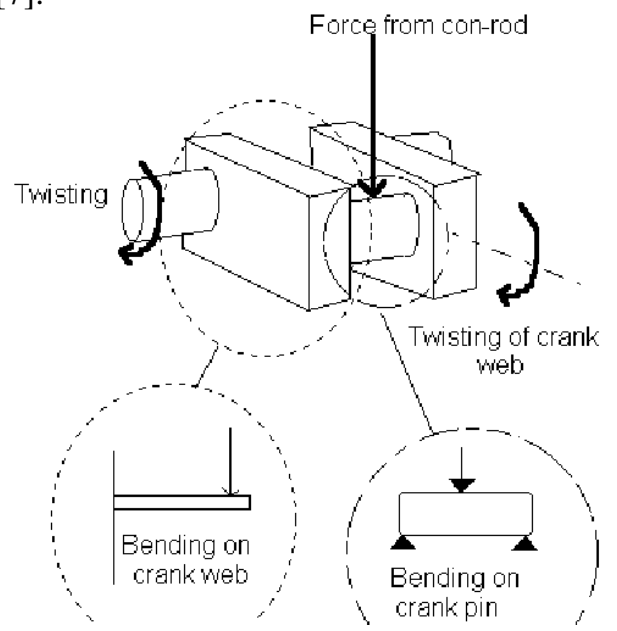

Figure 2: Forces and moment in crankshaft [1]

\section{Volume 6 Issue 7, July 2017 www.ijsr.net}




\section{International Journal of Science and Research (IJSR) \\ ISSN (Online): 2319-7064}

Index Copernicus Value (2015): 78.96 | Impact Factor (2015): 6.391

The crankshaft is subjected to various forces Figure 3 [8] but generally needs to be analyzed in two positions. Firstly, failure may occur at the position of maximum bending; this may be at the centre of the crank or at either end. In such a condition the failure is due to bending causes the pressure in the cylinder is maximal. Second, the crank may fail due to twisting. The pressure at this position is the maximum. Since the crankshaft is subjected to millions of repetitive cyclic loading, there are two different load sources in the crankshaft. The first load source is the inertia of rotating components (e.g. connecting rod) which increases with an increase in engine speed. This force is directly related to the rotating speed and acceleration of rotating components. The second load source is the force applied to the crankshaft due to gas combustion in the cylinder. Crankshaft experiences large forces from gas combustion. This force is applied to the top of the piston and since the connecting rod connects the piston to the crankshaft, the force will be transmitted to the crankshaft. This magnitude of the force transmitted depends on many factors which consist of crank radius, connecting rod dimensions, and weight of the connecting rod [8]. Thus, this inertia and combustion forces acting on the crankshaft cause two types of loading on the crankshaft produces torsional load and bending load.

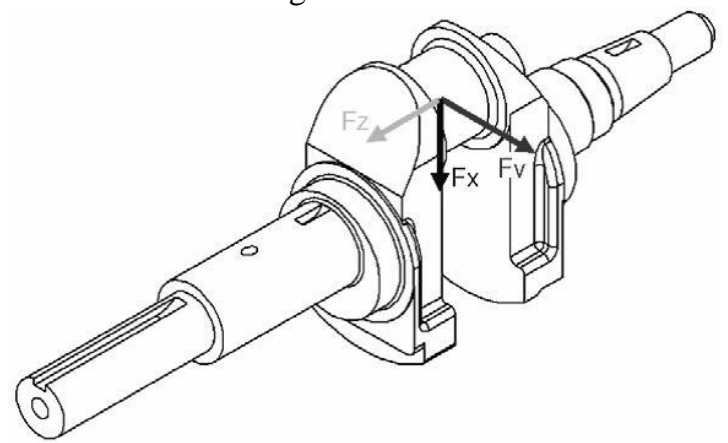

Figure 3: Crankshaft geometry and bending $\left(\mathrm{F}_{\mathrm{x}}\right)$, torsional $\left(\mathrm{F}_{\mathrm{y}}\right)$, and longitudinal $\left(\mathrm{F}_{\mathrm{z}}\right)$ force directions

The maximum load occurs at 355 degrees of crank angle when combustion takes place Figure 4. At this moment, force acting on the crankshaft is just bending load since the direction of the force is exactly towards the center of the crank radius

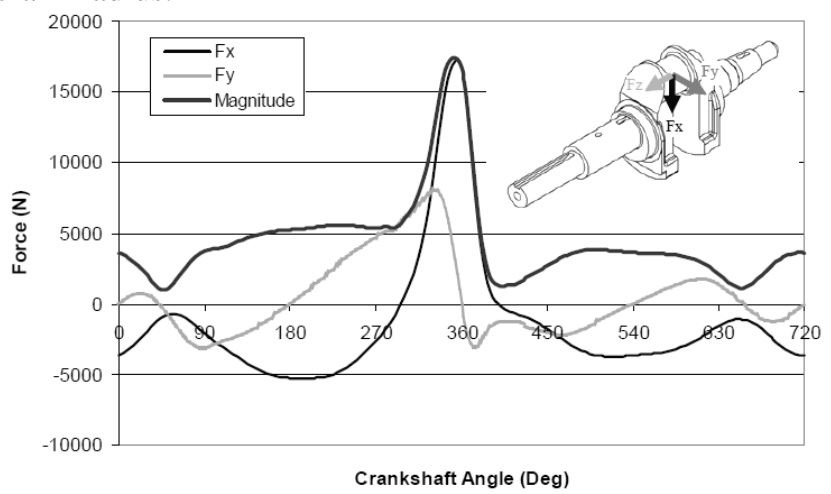

Figure 4: Bending, Torsional and Total resultant force at the connecting rod bearing [6]

\subsection{Material for the crankshaft}

Material model and material properties plays an important role in the interpretation of FE results. The cyclic material properties are used to calculate the elastic/plastic stress-strain response and the rate at which fatigue damage accumulate during each cycle. Since the crankshaft experiences a large number of load cycles during its service life, its fatigue performance and durability has to be considered in the design process. This section describes the various findings of materials and its mechanical properties for maintaining the durability of crankshaft. The major crankshaft material competitors currently used in industry are forged steel, and cast iron. Comparison of the performance of these materials with respect to static, cyclic, and impact loading are of great interest to the automotive industry. Zoroufi and Fatemi [9] performed fatigue evaluation and comprehensive comparisons of the forged steel and ductile cast iron crankshaft material and manufacturing process technologies with respect to their mechanical properties and durability performance as well as bench testing and experimental techniques. They performed experiment on the forged steel (AISI 1045) and ductile cast iron. Table 1 shows the chemical composition for forged steel and ductile cast iron.

Table 1: Chemical composition of forged steel and ductile cast iron by percent weight [2]

\begin{tabular}{|c|c|c|}
\hline Elements & Forged Steel & Ductile Cast Iron \\
\hline $\mathrm{C}$ & 0.45 & 3.44 \\
\hline $\mathrm{Mn}$ & 0.81 & 0.48 \\
\hline $\mathrm{P}$ & 0.016 & 0.019 \\
\hline $\mathrm{S}$ & 0.024 & 0.004 \\
\hline $\mathrm{Si}$ & 0.27 & 2.38 \\
\hline $\mathrm{Al}$ & 0.033 & 0.01 \\
\hline $\mathrm{Cr}$ & 0.1 & 0.09 \\
\hline $\mathrm{Ni}$ & 0.05 & 0.06 \\
\hline $\mathrm{Cu}$ & 0.13 & 0.31 \\
\hline $\mathrm{N}$ & 0.008 & -- \\
\hline $\mathrm{O}$ & $13 \mathrm{ppm}$ & -- \\
\hline
\end{tabular}

Superimposed plots of monotonic and cyclic true stress versus true strain for both materials are shown in Figure 5. It observed that for forged steel the cyclic stress-strain curve is below the monotonic curve. This indicates that the forged steel cyclically softened. Whereas, for ductile cast iron the cyclic stress-strain curve is above the monotonic curve, which indicates that it cyclically hardened [2].

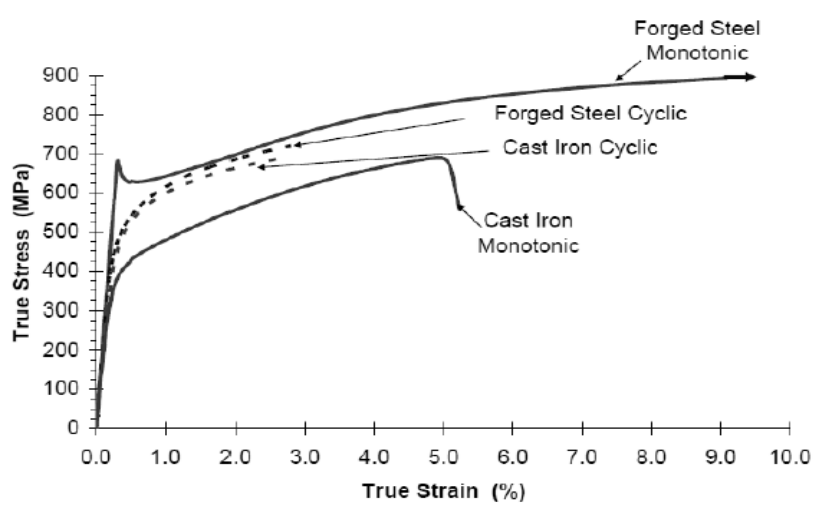

Figure 5: Cyclic stress-strain curves for forged steel and ductile cast iron [2]

\section{Forces on Crankshaft}

A crankshaft is subjected to bending and torsional moments due to the three forces [10]:

\section{Volume 6 Issue 7, July 2017 www.ijsr.net}




\section{International Journal of Science and Research (IJSR) \\ ISSN (Online): 2319-7064}

Index Copernicus Value (2015): 78.96 | Impact Factor (2015): 6.391

1) Forces exerted by the connecting rod on the crankpin

2) Weight of the flywheel acting downward in the vertical direction

3) Resultant belt tensions acting in the horizontal direction

Piston and connecting rod are connected by the piston pin at one end of connecting rod and other big end of connecting rod than connected to crankshaft. Gas pressure by hot gases on piston $F_{P}$, force on connecting $\operatorname{rod} F_{Q}$ and forces on crankshaft as shown in Figure 6,

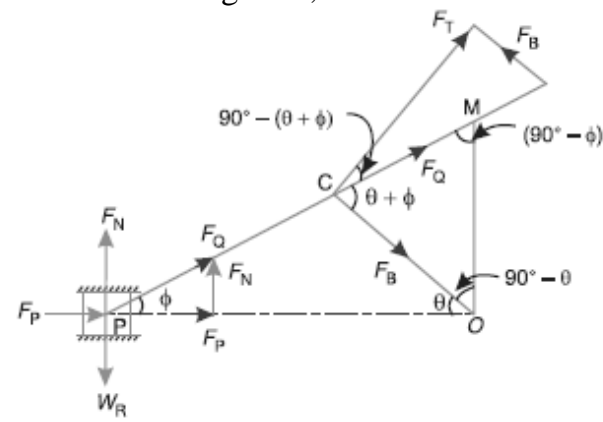

Figure 6: Schematic of forces in crankshaft

Crank-pin effort and thrust on crank shaft bearings. The force acting on the connecting rod $F_{Q}$ may be resolved into two components, one perpendicular to the crank and the other along the crank [10]. The component of $F_{Q}$ perpendicular to the crank is known as crank-pin effort and it is denoted by $F_{T}$. The component of $F_{Q}$ along the crank produces a thrust on the crank shaft bearings and it is denoted by $\mathrm{F}_{\mathrm{B}}$.

$$
\begin{aligned}
& F_{T}=F_{Q} \sin (\theta+\phi)=\frac{F_{P}}{\cos \phi} \times \sin (\theta+\phi) \\
& F_{B}=F_{Q} \cos (\theta+\phi)=\frac{F_{P}}{\cos \phi} \times \cos (\theta+\phi)
\end{aligned}
$$

Crank effort or turning moment or torque on the crank shaft. The product of the crankpin effort $F_{T}$ and the crank pin radius $r$ is known as crank effort or turning moment or torque on the crank shaft.

Crank effort,

$$
T=F_{T} \times r=F_{P}(\sin \theta+\cos \theta \tan \phi) \times r
$$

A typical drawing of crankshaft is shown in figure for the loading and design parameters.

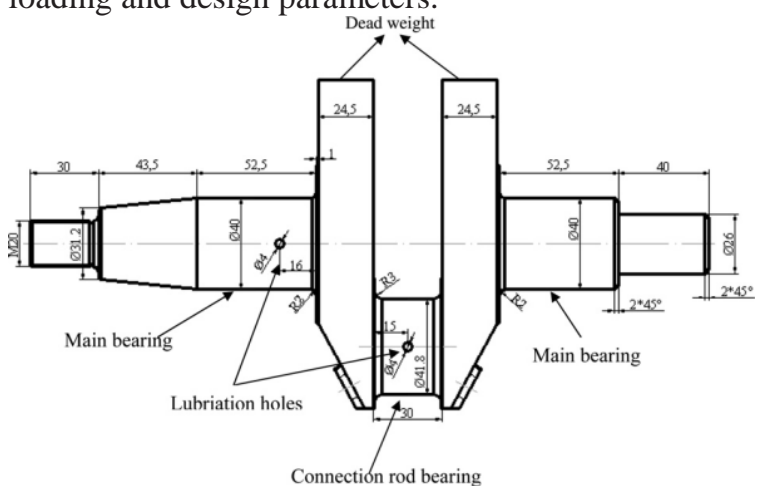

Figure 7: Technical drawing of the typical crankshaft [11]

\subsection{Maximum stress locations in Crankshaft}

In order to obtain stresses at different locations applying a load on crankpin in downward direction along cylinder axis when piston at TDC, while the bearing end is gripped in the fixed position. The maximum stress obtained at fillet radius of crankpin and near bearing ends as shown below,

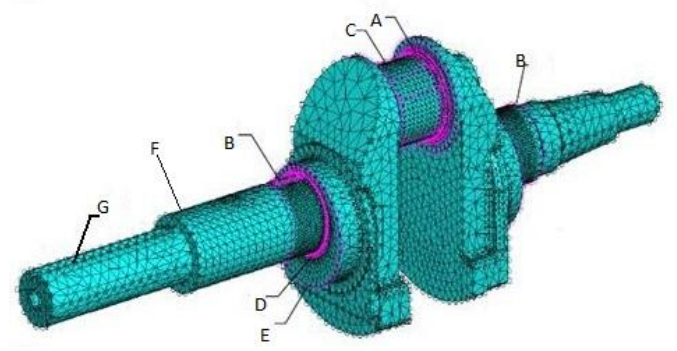

Figure 8: Stress calculation by FEM in crankshaft
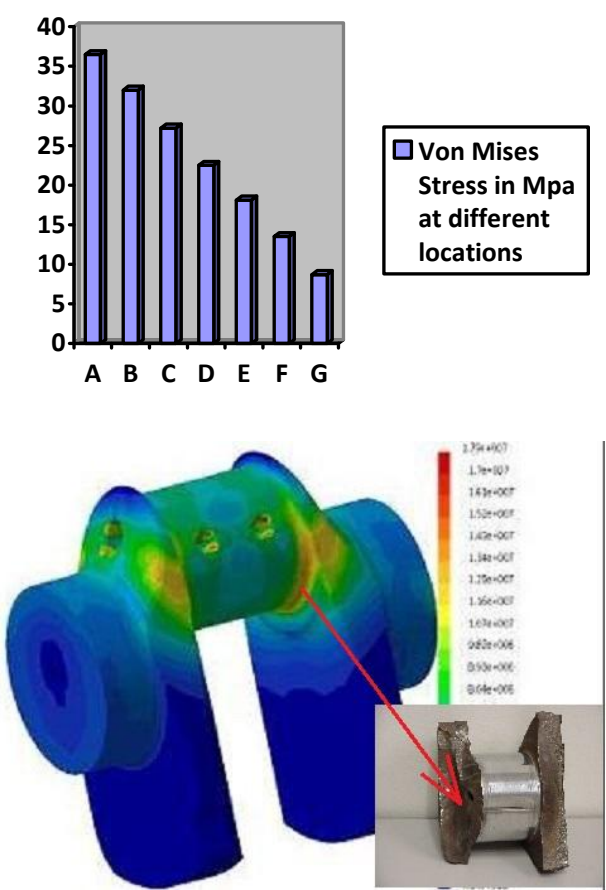

Figure 9: Failure of crankshaft

\section{Crank Shaft Design Parameters Optimization}

In order to carry out optimization process, it is necessary to have knowledge of the component dimensions, its service conditions, material construction, manufacturing process, and other parameters that affect its cost. The main factor considered during optimization is stress range under dynamic load within permissible limits. In the optimization process there is no change in the engine block and the connecting rod.

The following design parameters have been fixed to make the crankshaft interchangeable, Outer diameters of different cylinders, Crank radius, Location of main bearings (distance between them), Geometry of main bearings Thickness and geometry of connecting rod bearing

\subsection{Design Variables}

The parameters that are important variable for the optimization process are known as design variables as shown in Figure 10 are mainly [12]:

\section{Volume 6 Issue 7, July 2017 www.ijsr.net}




\section{International Journal of Science and Research (IJSR) \\ ISSN (Online): 2319-7064}

Index Copernicus Value (2015): 78.96 | Impact Factor (2015): 6.391

- Crankpin fillet radius

- Web angle

- Crankpin oil hole diameter

- Crank web thickness

- Depth of drilled hole at the back of crankshaft

- Diameter of drilled hole at the back of crankshaft

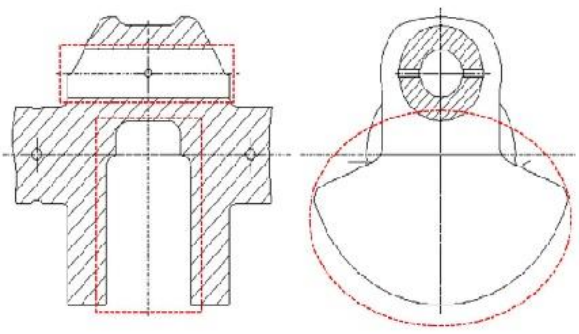

Figure 10: Critical design variables

The general flow chart for the optimization process, Objective function, design variables, and constraints are summarized as input and it is shown in Figure 11 that the optimization process consisting of geometry modifications, manufacturing process considerations and material alternatives are performed simultaneously.

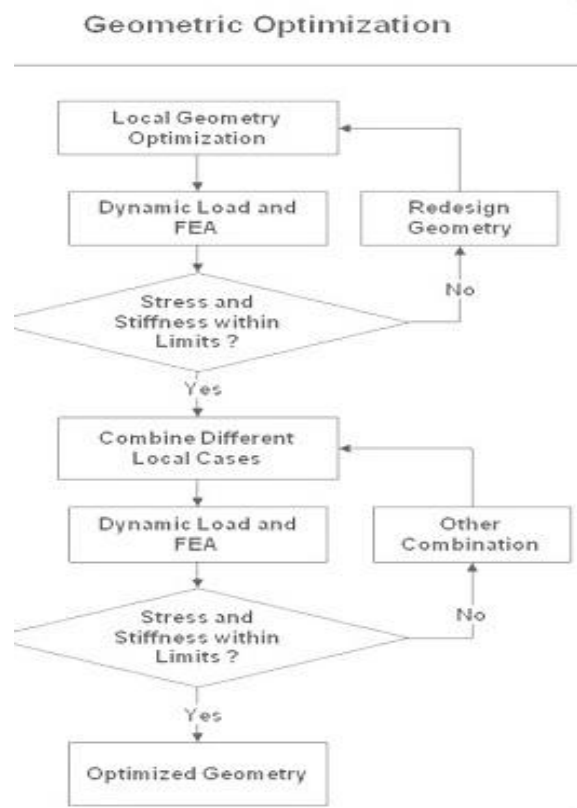

Figure 11: Geometry optimization flowchart for crankshaft

The effects of their critical dimensions such as crank web thickness, crankpin oil hole diameter, crankpin fillet radius, on maximum stresses generated at the critical locations under the fully reversible cyclic loading as shown in Figure 12.

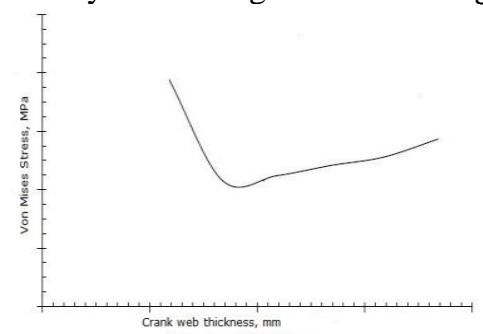

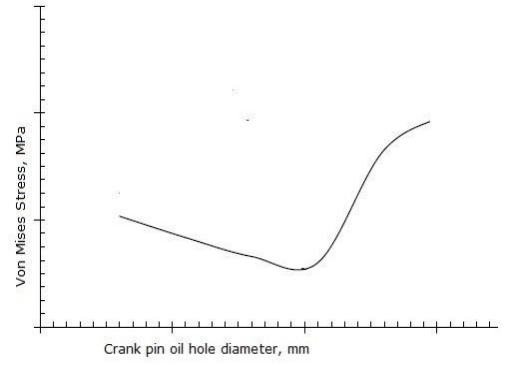

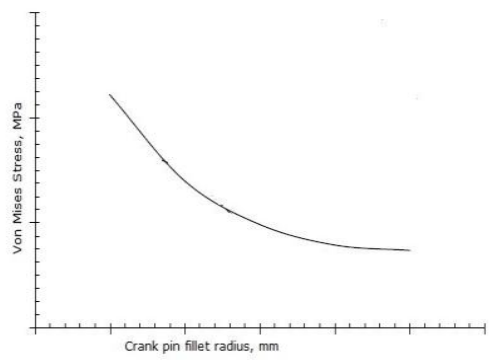

Figure 12: Effect of design variables on Von Mises stresses at critical location

\section{Fatigue Analysis of Crankshaft}

The conventional life estimation procedure for the fatigue analysis in which geometry, material and mechanical loading are regarded as three input parameters as shown in Figure 13.

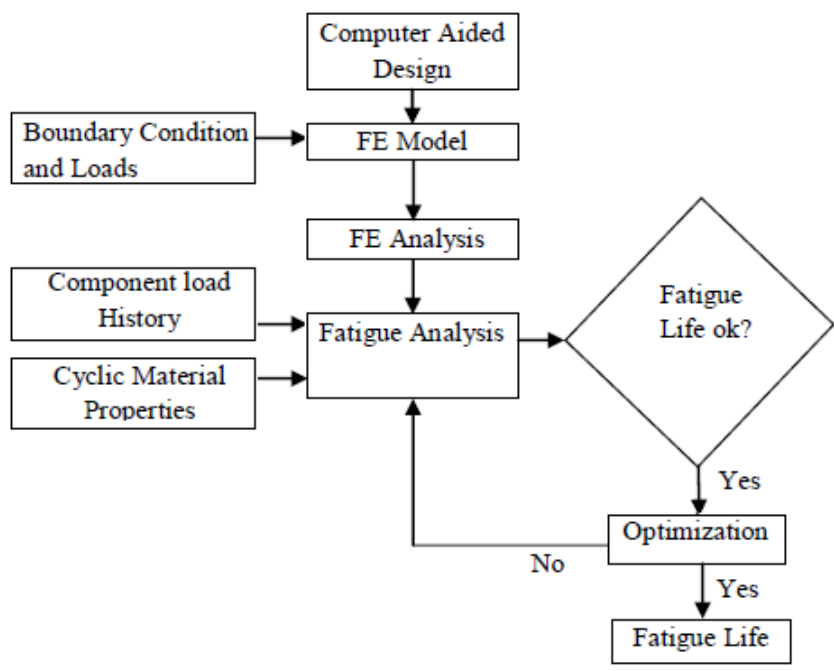

Figure 13: Flow chart of finite element based fatigue analysis for life estimation [13]

The fatigue resistance of metals can be characterized by a strain-life curve as shown in Figure 14. Coffin [14] and Manson [15] established a mathematical relationship between the total strain amplitude, and the reversals to failure cycles as,

$$
\frac{\Delta \varepsilon}{2}=\frac{\sigma_{f}^{\prime}}{E}\left(2 N_{f}\right)^{b}+\varepsilon_{f}^{\prime}\left(2 N_{f}\right)^{c}
$$

Morrow [16] established a relationship between the mean stress, and fatigue life as,

$$
\varepsilon_{a}=\frac{\sigma_{f}^{\prime}-\sigma_{\text {mean }}}{E}\left(2 N_{f}\right)^{b}+\varepsilon_{f}^{\prime}\left(2 N_{f}\right)^{c}
$$

Smith et al. [17] established another relationship, SmithWatson-Topper (SWT) mean stress correction model, expressed as,

\section{Volume 6 Issue 7, July 2017 www.ijsr.net}




\section{International Journal of Science and Research (IJSR) \\ ISSN (Online): 2319-7064}

Index Copernicus Value (2015): 78.96 | Impact Factor (2015): 6.391

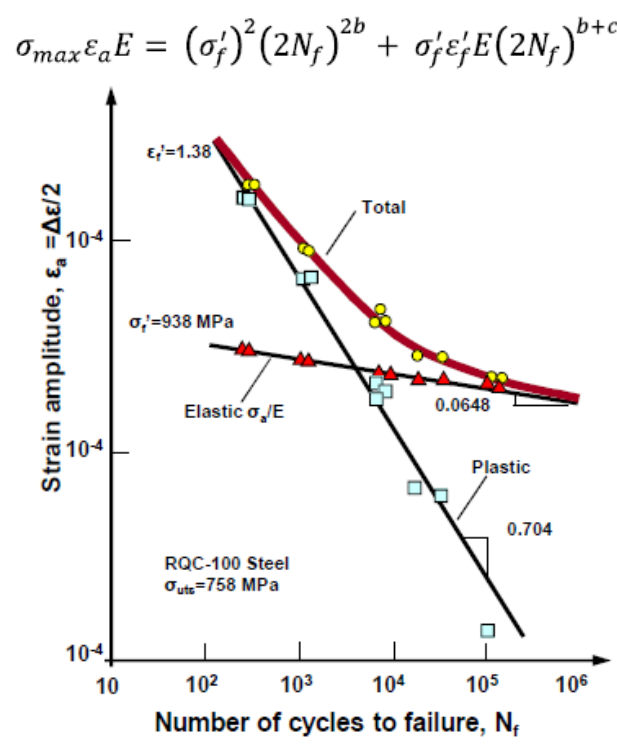

Figure 14: Strain-life curve [18]

Table 2: Mechanical properties of crankshaft material [2]

\begin{tabular}{|l|c|}
\hline Monotonic Properties & Forged Steel $(\mathrm{FS})$ \\
\hline Young's Modulus $(E), \mathrm{GPa}$ & 221 \\
\hline Yield Strength $\left(S_{Y}\right), \mathrm{MPa}$ & 625 \\
\hline Ultimate Tensile Strength $\left(S_{u}\right), \mathrm{MPa}$ & 827 \\
\hline Strength Coefficient $(K), \mathrm{MPa}$ & 1316 \\
\hline Strain Hardening Exponent $(n)$ & 0.152 \\
\hline Density, $\mathrm{kg} / \mathrm{m}^{3}$ & 7833 \\
\hline Poisson's Ratio & 0.30 \\
\hline Fatigue Properties \\
\hline Fatigue Strength Coefficient $\left(\sigma_{f}^{\prime}\right), \mathrm{MPa}$ & 1124 \\
\hline Fatigue Strength Exponent $(b)$ & -0.079 \\
\hline Fatigue Ductility Coefficient $\left(\varepsilon_{f}^{\prime}\right)$ & 0.671 \\
\hline Fatigue Ductility Exponent $(c)$ & -0.597 \\
\hline Cyclic Yield Strength $\left(S_{Y}{ }^{\prime}\right) \mathrm{MPa}$ & 505 \\
\hline Cyclic Strength Coefficient $\left(K^{\prime}\right), \mathrm{MPa}$ & 1159 \\
\hline Cyclic Strain Hardening Exponent $\left(n^{\prime}\right)$ & 0.128 \\
\hline
\end{tabular}

For entire range of force cycles, the fatigue results for forged steel crankshaft based on three different strain-life theories are compared. The fatigue life using Coffin-Manson is conservative as compared to Morrow and SWT strain-life theories; alternatively, Coffin-Manson theory estimates lower fatigue life; hence, safe for the design for forged steel crankshaft.

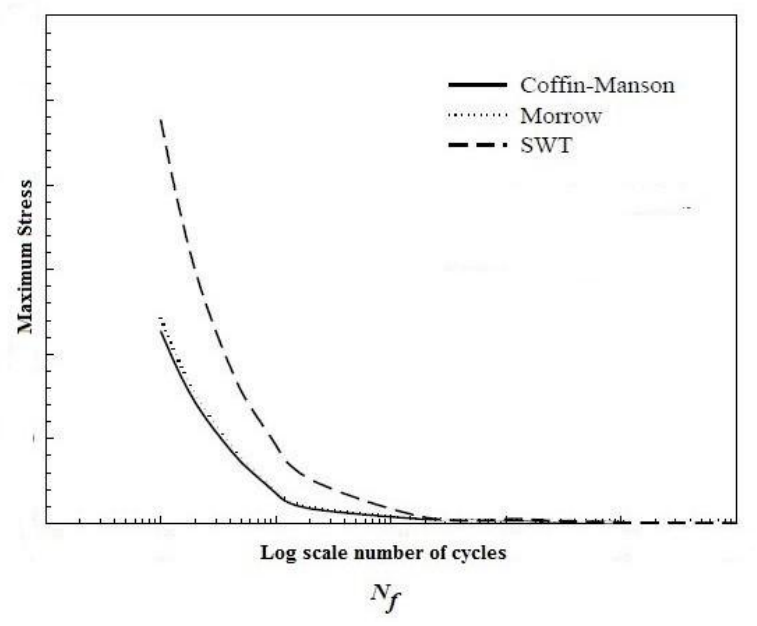

\section{Conclusions}

In this paper, the design of crankshaft and forces on shaft with respect to crank angle and the torque applied to crank is studied. Materials selection and design methodology has been presented. Paper reveals the design optimization of parameters like fillet radius, oil hole and web thickness and the relation to maximum stress at critical locations. The finite element analysis is very popular method to deal with the problem of stress analysis when geometry of the object is complicated and loading conditions are complex. The fatigue in crankshaft using different criteria and fatigue life prediction is presented.

\section{References}

[1] Amit Solanki, Ketan Tamboli and M. J. Zinjuwadia, 1314 May 2011, "Crankshaft Design and Optimization- A Review", National Conference on Recent Trends in Engineering \& Technology, B.V.M. Engineering College, V.V. Nagar, Gujarat, India

[2] Williams, J. and Fatemi, A., 2007, "Fatigue Performance of Forged Steel and Ductile Cast Iron Crankshafts", SAE Technical Paper No. 2007-01-1001, Society of Automotive Engineers

[3] http://www.ustudy.in/sites/default/files/images/cranksha ft.gif (downloaded on 22-07-2012

[4] Chatterley, T. C. and Murell, P., 1998, "ADI Crankshafts - An Appraisal of Their Production Potentials", SAE Technical Paper No. 980686, Society of Automotive Engineers

[5] Dubensky, R. G., 2002, "Crankshaft Concept Design Flowchart for Product Optimization”, SAE Technical Paper No. 2002-01-0770, Society of Automotive Engineers

[6] Montazersadgh, F. H. and Fatemi, A., August 2007 "Stress Analysis and Optimization of Crankshafts Subject to Dynamic Loading", Masters Thesis, The University of Toledo, Toledo, OH, USA

[7] Anthony P. Sime, B.Eng, October 1998 "Stress Analysis of Overlapped Crankshafts", Thesis submitted to the University of Nottingham

[8] Montazersadgh, F. H. and Fatemi, A., 2007, "Dynamic Load and Stress Analysis of a Crankshaft," SAE Technical Paper No. 2007-01-0258, Society of Automotive Engineers, Warrendale, PA, USA

[9] Zoroufi, M. and Fatemi, A., November 2005, "A Literature Review on Durability Evaluation of Crankshafts Including Comparisons of Competing Manufacturing Processes and Cost Analysis", 26th Forging Industry Technical Conference, Chicago, IL

[10] Khurmi, R. S. and Gupta, J. K., 2000, “A Test Book of Theory of Machines", S. Chand \& Company Ltd.

[11] $\mathrm{Yu} \mathrm{Z}, \mathrm{Xu} \mathrm{X}$. Failure analysis of a diesel engine crankshaft. Eng Failure Anal 2005;12:487-9

[12] V C Shahane et al.," Optimization of the crankshaft using finite element analysis Approach", DOI 10.1007/s41104-016-0014-0 Springer International Publishing Switzerland 2016

[13] Rahman, M.M., Kadirgama, K., Noor, M.M., Rejab, M.R.M., Kesulai, S.A., 2009, "Fatigue Life Prediction 
of Lower Suspension Arm Using Strain-Life Approach", European Journal of Scientific Research, Vol. 30 No. 3, pp. 437-450

[14] Coffin, L.F., 1954, “A Study Of The Effects of Cyclic Thermal Stresses on A Ductile Metal", Transactions of American Society for Testing and Materials, 76, pp. 931-950

[15] Manson, S.S., 1953, "Behavior of Materials Under Conditions of Thermal Stress", Heat Transfer Symposium, pp. 9-75

[16] Morrow, J., 1968, "Fatigue Design Handbook-Advances in Engineering” Warendale, PA, SAE, pp. 21-29

[17] Smith, K.N., Watson, P. and Topper, T.H., 1970, “A Stress-Strain Functions for the Fatigue on Materials", J. of Materials. 5(4), pp. 767-78

[18] Bishop, N., and Sherratt, F., 2000, "Finite Element Based Fatigue Calculations", The Int. Association for the Engg. Analysis Community Netherlands, NAFEMS Ltd

Volume 6 Issue 7, July 2017 www.ijsr.net 